\title{
Life cycle and distribution of Calanus finmarchicus in deep basins on the Nova Scotia shelf and seasonal changes in Calanus spp.
}

\author{
D. D. Sameoto ${ }^{1}$, A. W. Herman ${ }^{2}$ \\ ${ }^{1}$ Biological Sciences Branch, Department of Fisheries and Oceans, Bedford Institute of Oceanography, PO Box 1006 , \\ Dartmouth, Nova Scotia, Canada B2Y 4A2 \\ ${ }^{2}$ Physical/Chemical Sciences Branch, Department of Fisheries and Oceans, Bedford Institute of Oceanography, PO Box 1006 , \\ Dartmouth, Nova Scotia, Canada B2Y 4 A2
}

\begin{abstract}
The deep basins on the Nova Scotia shelf contain high concentrations of Calanus finmarchicus, C. glacialis, and C. hyperboreus at depths below $200 \mathrm{~m}$. From May to late fall these were as high as $20000 \mathrm{~m}^{-3}$. The dominant species by numbers was $C$. finmarchicus; however, its biomass was equalled or exceeded by $C$. hyperboreus. The life cycle of $C$. finmarchicus in the region of 2 of the largest basins showed that breeding started late in winter with a peak in April. High concentrations of Calanus suggested that the basins had higher levels of $C$. finmarchicus production than the adjacent shelf with mean depths less than $100 \mathrm{~m}$. All 3 species of Calanus started to accumulate below $200 \mathrm{~m}$ in May as Stages CIV and CV C. glacialis and C. hyperboreus did not reproduce in significant numbers on the NW half of the shelf but did accumulate in the basins as they were advected from the NE shelf region. Resting stages of Calanus resided at depths below $200 \mathrm{~m}$ in water at between 8.5 and $11^{\circ} \mathrm{C}$ for an estimated 7 to $8 \mathrm{mo}$. The fate of these copepods is uncertain, but evidence suggested that a large proportion were preyed on by euphausiids in the deep regions of the basin. The deep basins on the shelf make it possible for $C$. finmarchicus populations to dominate the Nova Scotia shelf zooplankton community for most of the year; without the basins the shelf zooplankton would probably resemble that of the Grand Banks which has no deep basins, and is dominated by microzooplankton.
\end{abstract}

\section{INTRODUCTION}

Deep basins are not common features on most continental shelves and their influences on the distribution and production of zooplankton and fish populations on shelves is unknown. The Nova Scotian shelf contains a large number of basins greater than $200 \mathrm{~m}$ depth that make up ca $5 \%$ of the total area of the shelf. Two of the largest basins, Emerald and La Have, are known to contain large populations of silver hake Merluccius bilinearis that feed principally on the euphausiid Meganyctiphanes norvegica (Koeller et al. in press), and acoustic data (Sameoto \& Cochrane 1985) have shown the presence of a large euphausiid population in Emeraid Basin. Herman (1988) reported an increase in zooplankton concentrations below a depth of $200 \mathrm{~m}$ during the fall in Emerald Basin and Louisbourg basins (Fig. 1). Concentrations of zooplankton deep in Emerald Basin were dominated by the copepod Calanus finmarchicus, whereas in Louisbourg Basin 3 species of Calanus, C. finmarchicus, C. glacialis and C. hyperboreus, were present in similar concentrations (Lewis \& Sameoto 1989).

Calanus finmarchicus, C. glacialis and C. hyperboreus are oceanic species which have life cycles that include a seasonal vertical migration (Ostvedt 1955, Conover 1988). Copepodite Stages IV and V migrate from the surface to depths between 400 and $1000 \mathrm{~m}$ in the open ocean every summer and fall, where they remain until the spring when as mature females they return to the surface waters to reproduce. This pattern is found in all open ocean regions where these species occur, with differences in the timing of the reproductive period occurring in different geographic regions (Conover 1988).

Calanus finmarchicus, C. glacialis and C. hyperboreus are all common expatriates from oceanic regions on the Nova Scotia shelf, with C. finmarchicus dominating the zooplankton community during the spring and early summer period (Sameoto 1982, 1984, 


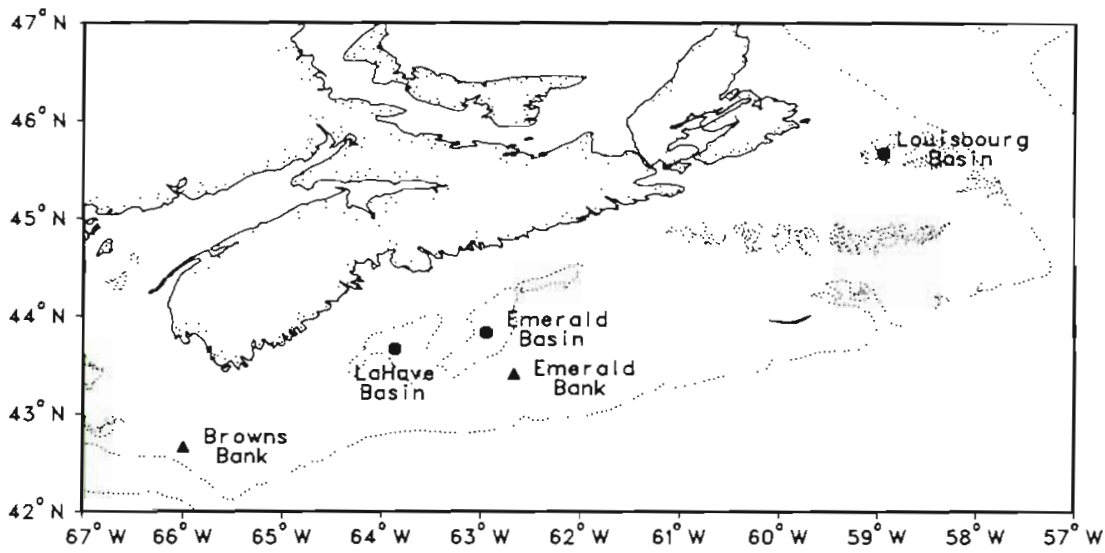

Fig. 1. Positions of zooplankton stations and locations of the deep basins and banks on the Nova Scotia shelf. Dotted lines represent the $200 \mathrm{~m}$ contour of the shelf edge and basins

Tremblay \& Roff 1983). Little is known about the vertical distribution of Calanus in the basins of the Scotian shelf at different times of the year, nor is anything known about the importance of these high concentrations of copepods in the deep regions of the basins to the total zooplankton community on the shelf. Earlier studies on zooplankton production and distribution (Tremblay \& Roff 1983, O'Boyle et al. 1984, McLaren et al. 1989) were based on data collected in the top $200 \mathrm{~m}$ of the water column and therefore missed the concentrations of zooplankton in the deep basins. This study describes seasonal changes in the Calanus community of Emerald and other basins and compares the production of C. finmarchicus in Emerald Basin to its estimated production on Emerald Bank (McLaren et al. 1989).

\section{METHODS}

The study area, sampled between 1984 and 1988, included the major basins on the Scotian shelf (Fig. 1) and stations on the shallow plains and banks. Mesozooplankton samples were taken with the Bedford Institute of Oceanography Net and Environment Sensing System (BIONESS), an opening and closing net sampler with 10 nets of $1 \mathrm{~m}^{2}$ mouth opening each with a mesh size of $243 \mu \mathrm{m}$ (Sameoto et al. 1980). The BIONESS also continuously measured temperature and salinity during tows by means of a Guildline Instruments digital conductivity, temperature and depth instrument (CTD). The flow through the nets was monitored with external and internal flowmeters. The BIONESS was towed at a speed of 3 knots as it was slowly lowered along an oblique path to the desired depth where the nets were opened and closed on command from the ship. Each net filtered between 30 and $150 \mathrm{~m}^{3}$ of water per sample. Samples were taken every 5 to $10 \mathrm{~m}$ depth stratum in the region from the surface to the thermocline, and at ca 10 to $20 \mathrm{~m}$ intervals below the thermocline.
Samples were also taken with an unmetered $0.75 \mathrm{~m}$ diameter opening and closing ring net, with a $246 \mu \mathrm{m}$ mesh, towed vertically at $1.5 \mathrm{~m} \mathrm{~s}^{-1}$. This sampler was used on ships of opportunity that were unable to operate the BIONESS and enabled us to obtain a time series of zooplankton vertical structure at a single station in Emerald Basin. The volume of water filtered by the ring net was estimated by multiplying the vertical distance it was towed by its mouth area. Because the net did not take into account the effect of currents or the ship's drift it probably underestimated water filtered and overestimated the numbers of zooplankton $\mathrm{m}^{-3}$ by between 20 and $30 \%$. However, because the exact degree of overestimation is unknown, no corrections were made to these data.

In situ zooplankton concentration and sizes were also measured using an optical zooplankton counter (Herman 1988). This instrument counted and sized particles between 0.5 and $20 \mathrm{~mm}$ in spherical diameter. It was mounted on the side of the BIONESS with a rectangular collecting net $(8.5 \times 30 \mathrm{~cm})$ in front of the sampler mouth. It provided in situ data of the zooplankton concentration during the profiles. The counter gave information on the vertical distribution of zooplankton with an effective resolution of ca $30 \mathrm{~cm}$. The counter's accuracy decreased with increased zooplankton density due to coincident counts. At concentrations greater than $4000 \mathrm{~m}^{-3}$ a coincidence correction is required (Herman 1988). The optical counter also measured light attenuation and thereby indirectly provided an approximate depth for the chlorophyll maximum (Herman et al. in press).

The zooplankton samples were preserved in a $5 \%$ formalin seawater solution buffered with sodium borate and strontium chloride. All samples were sorted for macrozooplankton (animals $>1 \mathrm{~cm}$ in length) and ichthyoplankton that were removed, identified, and weighed wet after excess water was removed by blotting. The remaining mesozooplankton sample was filtered over a $50 \mu \mathrm{m}$ screen under vacuum to remove the 
water until water ceased to drip from the filter and was then weighed to obtain a wet biomass. The sample was then split to obtain a subsample of about 400 animals using a Motoda splitter (Motoda 1959); these animals were identified to species and the Calanus spp. staged. The maturity stages of female $C$. finmarchicus were determined and classified into the following 3 categories:

(1) Developing females; ovaries formed, oviducts lightly colored, developing a few small pale eggs, abundant oil and the copepod in good condition.

(2) Gravid females; oviduct and body very dark and full of mature sized eggs, copepods in good condition.

(3) Spent females; oil in body depleted, oviducts with very little contents, female in poor condition and pale.
Oxygen concentrations in the total water column of Emerald Basin were determined from triplicate water samples collected at various depths with a rosette sampler or measured by means of an oxygen electrode mounted on a CTD.

\section{RESULTS}

\section{Physical oceanography of basins}

Deep regions of Emerald and La Have Basins differ from the shallow regions of the shelf during all seasons. Below ca $100 \mathrm{~m}$, the basins contain slope water with temperature and salinity much higher than found in the upper $100 \mathrm{~m}$ for most of the year (Fig. 2). The warm

\section{EMERALD BASIN JUNE 1988}
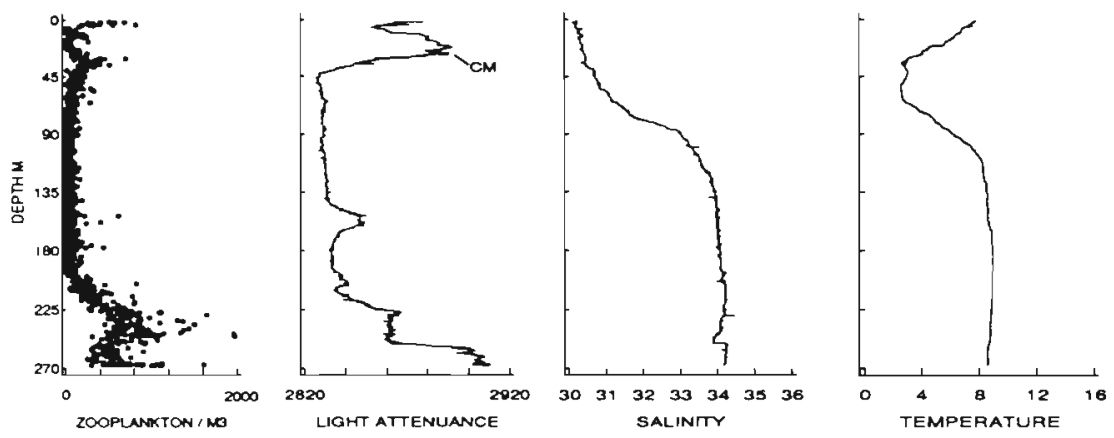

EMERALD BASIN SEPTEMBER 1985
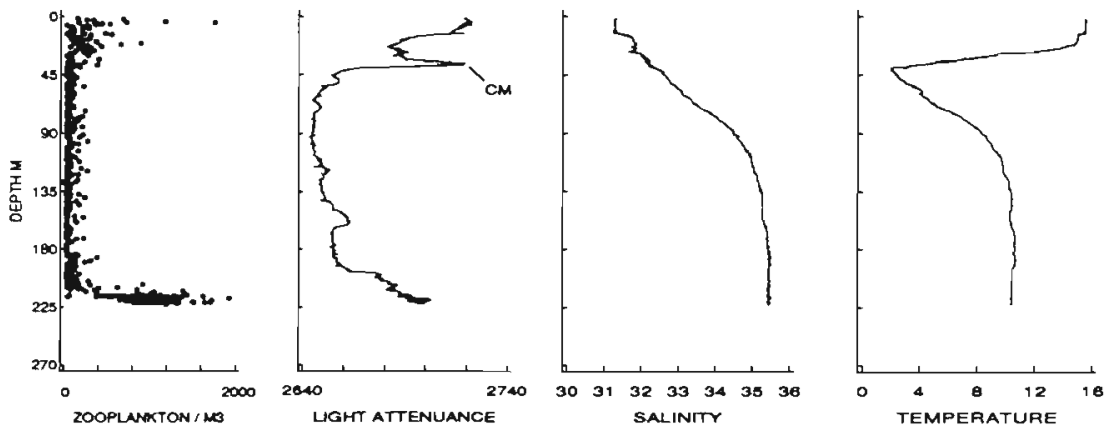

LOUISBOURG BASIN SEPTEMPER 1985

Fig. 2. Profiles of temperature, salinity, relative light attenuance and in situ opti. cal zooplankton concentration profiles for Emerald Basin during June and September, and profiles for Louisbourg Basin in September. Bottom depths: Emerald Basin $272 \mathrm{~m}$, Louisbourg Basin $285 \mathrm{~m}$. CM: chlorophyll maximum
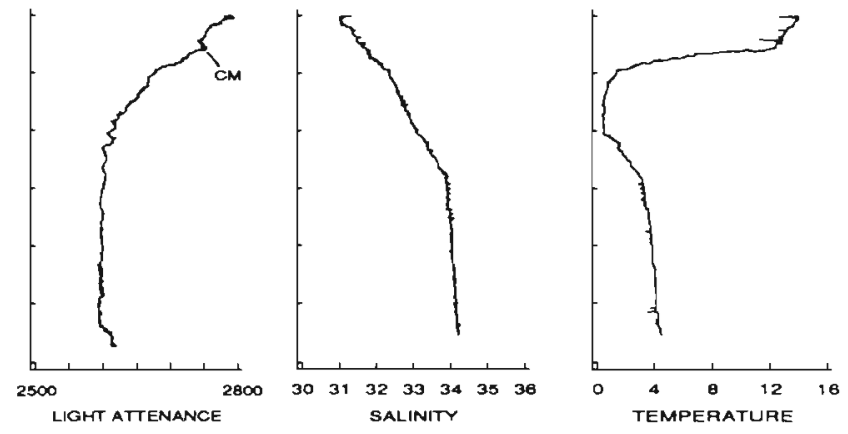
saline layer is a permanent feature (Drinkwater \& Taylor 1982, Drinkwater \& Trites 1987). These 2 basins are flushed by slope water intrusions several times during winter displacing the lower density basin water (Herman et al. in press). The mean upwelling velocity was estimated to be only $0.1 \mathrm{~mm} \mathrm{~s}^{-1}$, thereby presenting little or no displacement for the zooplankton resident in the deep regions of the basins. The basins on the NE shelf are not influenced by an inflow of warm slope water and the waters in the deeper regions of these basins are colder and less saline during all seasons of the year (Rowell et al. 1985, Drinkwater \& Trites 1987) (Fig. 2).

The light attenuation profiles in Emerald and La Have Basins during June and September generally showed a decrease from the surface to the depth of the chlorophyll maximum where a sharp increase occurred (Fig. 2). Below the chlorophyll maximum attenuation decreased sharply. From 50 to $160 \mathrm{~m}$ light attenuation remained relatively stable to $160 \mathrm{~m}$ where an increase occurred for a short depth interval and then a decrease at about $180 \mathrm{~m}$. Below $200 \mathrm{~m}$ the light attenuation increased to bottom.

The light attenuation in Louisbourg Basin during the fall was different from that of Emerald Basin in that there was little change in attenuation with depth below $100 \mathrm{~m}$. The large increase in attenuation below $200 \mathrm{~m}$ in Emerald Basin was not present and there was only a slight increase in attenuation in the bottom $20 \mathrm{~m}$ (Fig. 2).

\section{Distribution of zooplankton measured by optical counter}

Profiles of the concentrations of zooplankton $\mathrm{m}^{-3}$ made with the optical counter showed that the variability of concentration at successive depths was very small, generally less than twice the mean value (Fig. 2). The data suggest small localized areas with higher concentrations of zooplankton. The counter had a horizontal resolution of $2 \mathrm{~cm}$, the thickness of the detector light beam, and a vertical resolution of $30 \mathrm{~cm}$, the vertical dimension of the collecting net in front of the optical counter (Herman 1988).

The vertical pattern of zooplankton concentration was similar in all the basins during June and October, generally showing high concentrations in the upper $40 \mathrm{~m}$ and low concentrations from 40 to about $200 \mathrm{~m}$ (Fig. 2). Below $200 \mathrm{~m}$ there was a rapid increase in concentration to between 1300 and $4000 \mathrm{~m}^{-3}$

There was a positive relationship between sharp increases in light attenuation and in concentration of zooplankton $\mathrm{m}^{-3}$ in the upper $40 \mathrm{~m}$ in the Emerald Basin profiles. No relationship between zooplankton concentration and light attenuation was seen in Louisbourg Basin (Fig. 2). Particles in the water responsible for the increased light attenuation between 20 and $40 \mathrm{~m}$ were believed to be phytoplankton cells, because Herman (1988) showed a close relationship between the chlorophyll maximum layer and an increase in light attenuation at these depths. Below the euphotic zone, chlorophyll concentrations were $<0.1 \mathrm{mg} \mathrm{m}^{-3}$ (Herman et al. in press) and, therefore, the increased light attenuation below $140 \mathrm{~m}$ was probably detrital material with very little if any chlorophyll.

The concentrations of zooplankton did not show any obvious relationship with temperature or salinity in any of the zooplankton profiles. There was little change in the temperature and salinity below $200 \mathrm{~m}$ in all the basins, but yet in all of the profiles there was an increase in the concentrations of the copepods (Fig. 2).

The oxygen concentration of the slope water in Emerald Basin gradually decreased to ca $5 \mathrm{mg} \mathrm{l}^{-1}$ near the bottom during all months with no evidence of oxygen depletion near the bottom (Fig. 3). Oxygen levels in the basins on the northeastern end of the shelf were not measured.

\section{Season vertical distribution and abundance of Calanus spp.}

Calanus finmarchicus was the most abundant copepod in Emerald and La Have Basins during all sampling periods. Between February and October, $C$. finmarchicus represented up to $70 \%$ of the all mesozooplankton in the water column and C. glacialis and C. hyperboreus accounted for 1 to $27 \%$ of the total (Table 1). The main concentration was found in the deep part of Emerald Basin during all months except
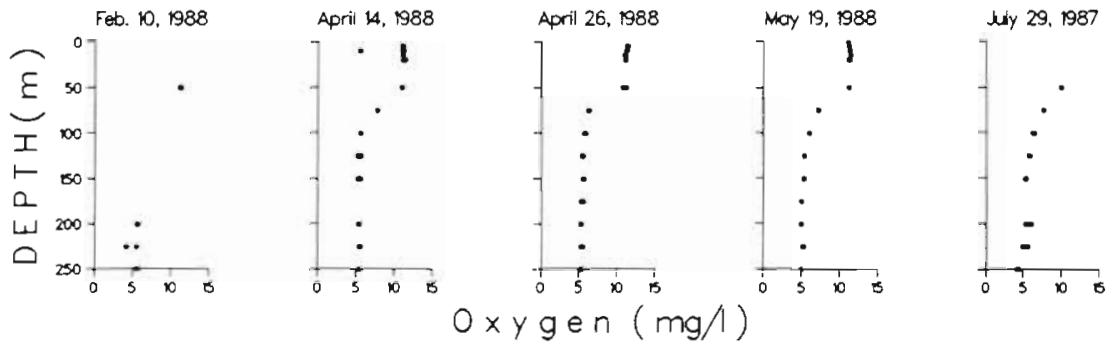

Fig. 3. Distribution of oxygen in Emerald Basin during different seasons 


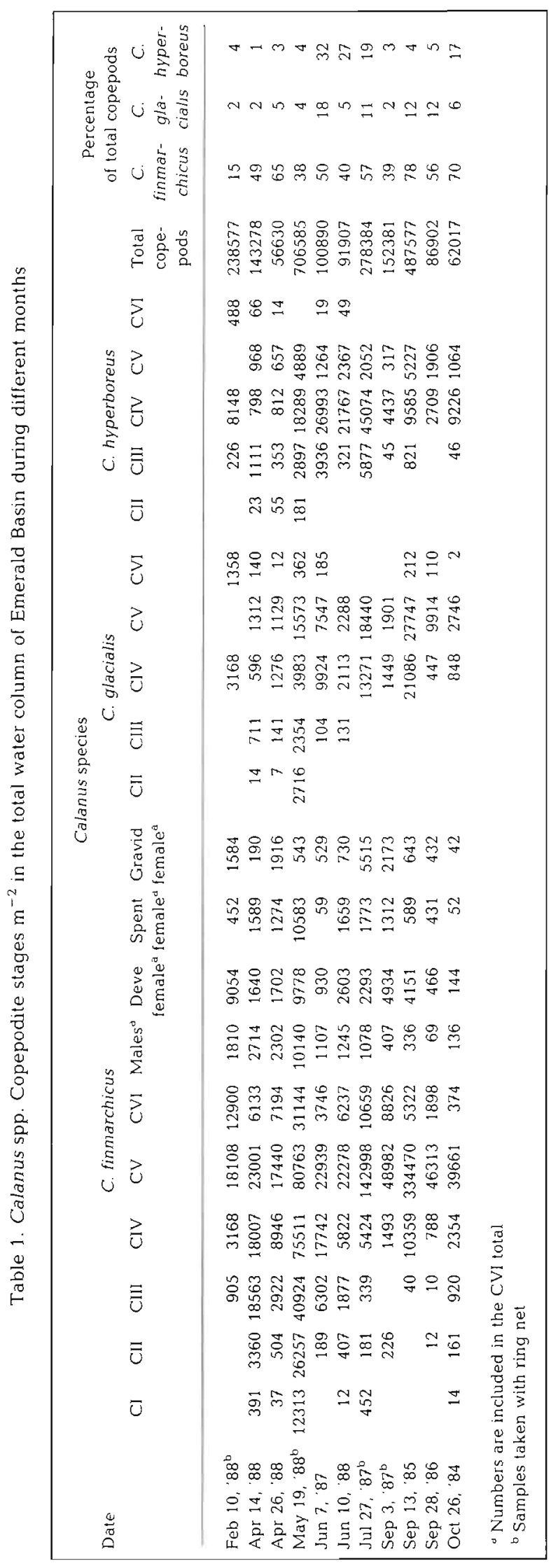

April. There was no evidence of a significant population of C. glacialis or C. hyperboreus in the upper $50 \mathrm{~m}$ during any of the sampled periods, which suggested that these species did not reproduce in the Emerald Basin region, but were probably advected from the northeastern region of the shelf where they were very common (Fig. 4) (Lewis \& Sameoto 1988a, b, c, 1989).

There were large seasonal changes in the vertical concentration of all 3 species of Calanus in Emerald Basin (Fig. 4). During February C. finmarchicus concentrations were low from the surface to about $225 \mathrm{~m}$, whereas below $225 \mathrm{~m}$ their concentrations increased sharply. This same pattern was also seen for $C$. hyperboreus but less so for $C$. glacialis. During April the highest concentrations of $C$. finmarchicus were at $20 \mathrm{~m}$ with no evidence of large concentrations below $200 \mathrm{~m}$, while the concentrations of $C$. finmarchicus, $C$. hyperboreus and C. glacialis below $200 \mathrm{~m}$ were the lowest of all (Table 2).

On May 19, the concentrations $\mathrm{m}^{-3}$ of Calanus finmarchicus in the top $40 \mathrm{~m}$ were similar to the April values but the concentrations below $40 \mathrm{~m}$ were higher, suggesting that the new generation of Stages CIV and $\mathrm{CV}$ were migrating into the deep water. The concentration of C. hyperboreus and C. glacialis showed an increase below $200 \mathrm{~m}$ in May, indicating that these species were also accumulating in the deep regions of the basins. On June 7, data continued to show a similar pattern to that seen in May for all 3 species of Calanus.

The July, September and October samples all showed similar patterns for the vertical distributions of the 3 Calanus spp. The highest concentration of $C$. finmarchicus below $200 \mathrm{~m}$ occurred in September; this suggested a continuous accumulation of copepods throughout the summer and fall (Fig. 4). The populations of the other 2 species of Calanus did not increase in the basin during the summer and fall, which indicated that these species were brought into Emerald Basin between May and July. However, year-to-year population variations make it impossible to make a definitive statement about the arrival time of these species into the basin.

The distribution of Calanus spp. on the shallow regions of the shelf was similar to the upper waters over the basins. But in June 1988, the concentrations of $C$. finmarchicus over Emerald Bank were more than an order of magnitude lower than those in the upper $50 \mathrm{~m}$ in Emerald Basin. The highest concentrations of $C$. finmarchicus on Emerald Bank in September were near the bottom, that suggested that the copepods were seeking deep water. The concentrations of $C$. finmarchicus on the bank were similar to those at the same depths in the Emerald Basin

The species composition of Calanus in Louisbourg Basin was significantly different to that of the Emerald 
E M E R A D B A NK

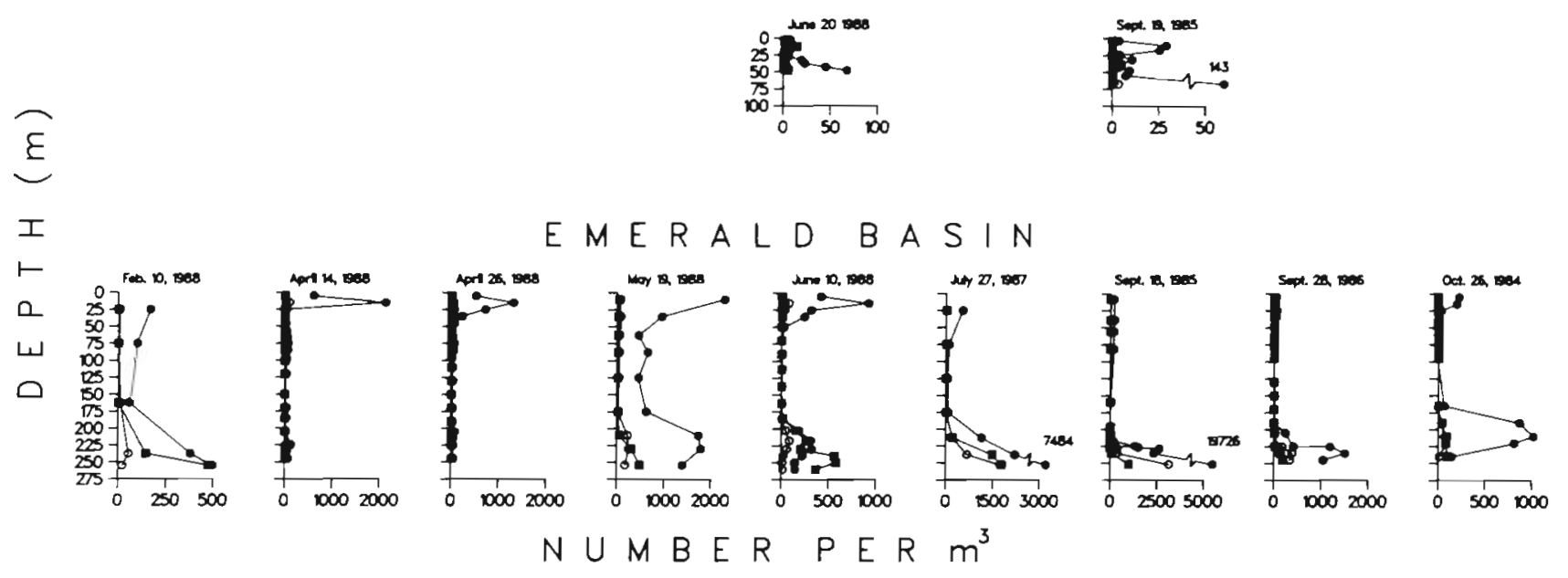

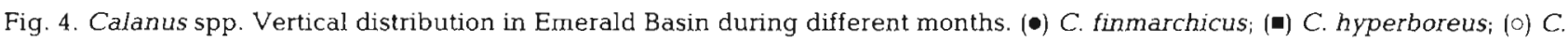
glacialis. Note different scales for numbers

and La Have Basins. In October the 3 Calanus species in Louisbourg Basin had similar concentrations $\mathrm{m}^{-2}$ (Table 2).

The basins in the NE half of the shelf were only sampled in June and October, but they showed similar vertical distribution patterns to Emerald and La Have Basins on these dates. The primary difference between the 2 regions was the higher concentrations of Calanus hyperboreus and C. glacialis in the NE and evidence of an accumulation in June of $C$. hyperboreus and $C$. glacialis but not $C$. finmarchicus in the deeper part of Louisbourg Basin during June (Fig. 5). It is possible that C. hyperboreus and C. glacialis developed to Stage IV earlier than $C$. finmarchicus or else underwent sea-

Table 2. Calanus spp. Concentrations $\mathrm{m}^{-2}$ and estimated percentage of Calanus volume of each species in deep regions (>200 $\mathrm{m}$ ) of the basins

\begin{tabular}{|c|c|c|c|c|c|c|c|c|c|c|}
\hline \multirow[t]{3}{*}{ Date } & \multirow{3}{*}{$\begin{array}{c}\text { Depth } \\
\text { range (m) }\end{array}$} & \multicolumn{9}{|c|}{ Calanus species } \\
\hline & & \multicolumn{3}{|c|}{ C. finmarchicus } & \multicolumn{3}{|c|}{ C. glacialis } & \multicolumn{3}{|c|}{ C. hyperboreus } \\
\hline & & $\begin{array}{l}\text { No. } \\
\mathrm{m}^{-2}\end{array}$ & $\begin{array}{l}\text { Percent } \\
\text { of total } \\
\text { Calanus } \\
\text { population }\end{array}$ & $\begin{array}{l}\text { Percent } \\
\text { of total } \\
\text { Calanus } \\
\text { biomass }\end{array}$ & $\begin{array}{l}\text { No. } \\
\mathrm{m}^{-2}\end{array}$ & $\begin{array}{c}\text { Percent } \\
\text { of total } \\
\text { Calanus } \\
\text { population }\end{array}$ & $\begin{array}{l}\text { Percent } \\
\text { of total } \\
\text { Calanus } \\
\text { biomass }\end{array}$ & $\begin{array}{l}\text { No. } \\
\mathrm{m}^{-2}\end{array}$ & $\begin{array}{c}\text { Percent } \\
\text { of total } \\
\text { Calanus } \\
\text { population }\end{array}$ & $\begin{array}{c}\text { Percent } \\
\text { of total } \\
\text { Calanus } \\
\text { biomass }\end{array}$ \\
\hline \multicolumn{11}{|c|}{ Emerald Basin } \\
\hline Feb 10, ' 88 & $225-260$ & 17140 & 63 & 36 & 1584 & 6 & 3 & 8610 & 31 & 60 \\
\hline Apr $14, ' 88$ & $190-250$ & 3586 & 63 & 20 & 454 & 8 & 3 & 1635 & 29 & 77 \\
\hline Apr 26, 88 & $200-268$ & 3398 & 71 & 25 & 316 & 7 & 2 & 1073 & 22 & 73 \\
\hline May $19,{ }^{\prime} 88^{\circ}$ & $200-268$ & 109688 & 75 & 32 & 14828 & 10 & 4 & 20968 & 14 & 64 \\
\hline Jun 07,87 & $195-250$ & 14410 & 29 & 13 & 10021 & 20 & 9 & 24695 & 50 & 79 \\
\hline Jun $10, ' 88$ & $195-265$ & 14305 & 37 & 14 & 2930 & 8 & 3 & 21240 & 55 & 84 \\
\hline Jul 06, '87 & $195-250$ & 13981 & 29 & 15 & 9614 & 20 & 11 & 24191 & 51 & 74 \\
\hline Jul $27,87^{\mathrm{a}}$ & $200-255$ & 125620 & 60 & 41 & 31110 & 15 & 10 & 51605 & 25 & 49 \\
\hline Sep 03, ' $87^{\mathrm{a}}$ & $200-230$ & 38010 & 85 & 63 & 2730 & 6 & 4 & 3990 & 9 & 33 \\
\hline Sep 18, ' 85 & $220-257$ & 259297 & 83 & 77 & 41384 & 13 & 12 & 12239 & 4 & 10 \\
\hline Sep 28, '86 & $200-250$ & 44310 & 75 & 51 & 10280 & 17 & 11 & 4540 & 8 & 38 \\
\hline Oct $26, ' 84$ & $200-240$ & 40230 & 72 & 49 & 3930 & 7 & 5 & 10338 & 21 & 46 \\
\hline \multicolumn{11}{|c|}{ La Have Basin } \\
\hline Jul 30,87 & $175-235$ & 61555 & 32 & 15 & 29960 & 16 & 7 & 100185 & 52 & 78 \\
\hline Oct $28,{ }^{\prime} 84$ & $200-230$ & 28247 & 69 & 45 & 4612 & 11 & 7 & 8015 & 20 & 48 \\
\hline \multicolumn{11}{|c|}{ Louisbourg Basin } \\
\hline Sep 21, '85 & $200-285$ & 134225 & 37 & 22 & 137745 & 38 & 23 & 88650 & 25 & 55 \\
\hline
\end{tabular}




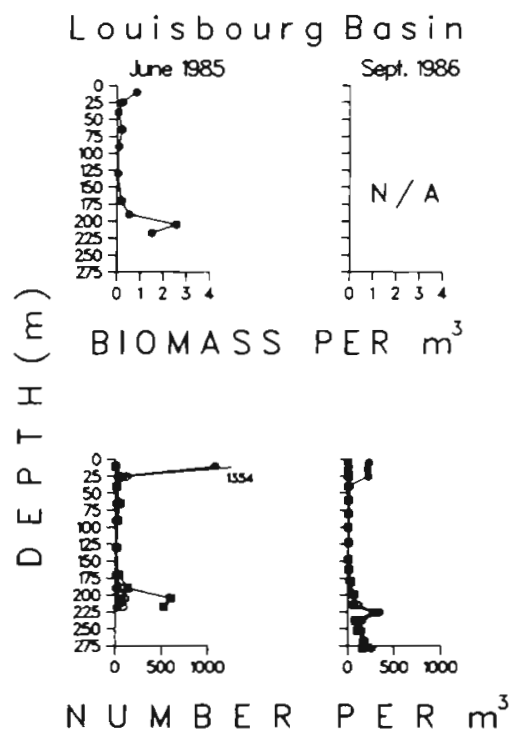

Fig. 5. Vertical distributions of concentration of Calanus spp. and of total zooplankton biomass $\mathrm{g} \mathrm{m}^{-3}$ in Louisbourg Basin. (•) C. finmarchicus; (-) C. hyperboreus; (ㅇ) C. glacialis; N/A: data lost

sonal vertical migration earlier or were remnants of an overwintering population.

\section{Day/night differences}

Calanus finmarchicus, C. hyperboreus and C. glacialis did not show any evidence of diumal vertical migration from below $200 \mathrm{~m}$ (Fig. 6).

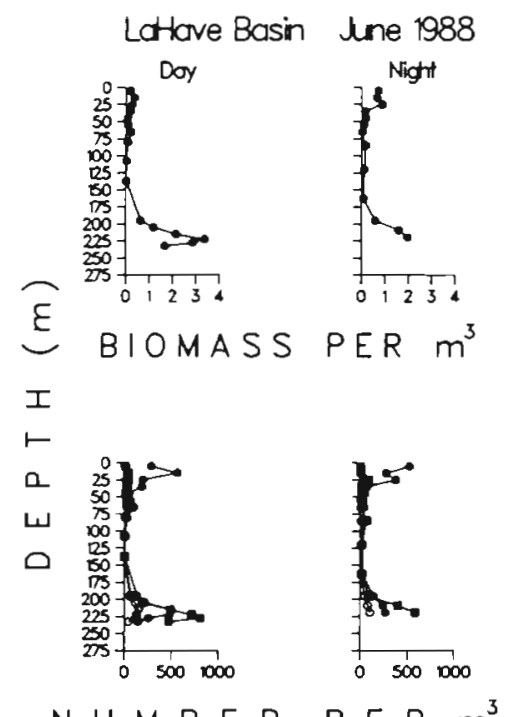

Fig. 6. Day/night vertical distribution of total numbers $\mathrm{m}^{-3}$ of Calanus spp. and total zooplankton biomass $\mathrm{g} \mathrm{m}^{-3}$ in La Have

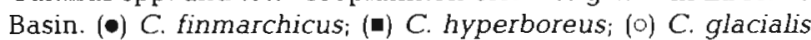

Table 3. Calanus spp. Percentages of copepodite stages below $200 \mathrm{~m}$ in Emerald Basin

\begin{tabular}{|c|c|c|c|c|c|c|}
\hline \multirow[t]{2}{*}{ Date } & \multicolumn{6}{|c|}{ Copepodite stage } \\
\hline & Male & Female CVI & $\mathrm{CV}$ & CIV & CIII & CII \\
\hline \multicolumn{7}{|c|}{ C. finmarchicus } \\
\hline Feb 10, '88 & 3 & 17 & 63 & 15 & 1 & \\
\hline Apг $14, \cdot 88$ & 8 & 8 & 69 & 10 & 4 & 1 \\
\hline Apr 26,88 & 27 & 12 & 48 & 10 & 2 & 0.5 \\
\hline May $19, ' 88$ & 7 & 5 & 38 & 20 & 16 & 9 \\
\hline Jun 10,88 & 8 & 2 & 85 & 3 & 1 & 0.5 \\
\hline Jul $27, ' 87$ & 0.4 & 4 & 92 & 3 & & \\
\hline Sep 03, 87 & 0.5 & 4 & 93 & 3 & & \\
\hline Oct 26,84 & 1 & 2 & 97 & 1 & & \\
\hline \multicolumn{7}{|l|}{ C. glacialis } \\
\hline Feb 10, '88 & & & & 100 & & \\
\hline Apr 14,88 & & 1 & 47 & 50 & 2 & 0.5 \\
\hline Apr 26,88 & & & 92 & 7 & 1 & \\
\hline May 19, ' 88 & & 18 & 71 & 12 & 7 & 7 \\
\hline Jun 10,88 & & & 67 & 33 & & \\
\hline Jul 27, '87 & & & 51 & 49 & & \\
\hline Sep 03, ' 87 & & & 53 & 47 & & \\
\hline Oct 26,84 & & & 87 & 13 & & \\
\hline \multicolumn{7}{|c|}{ C. hyperboreus } \\
\hline Feb 10,88 & & 1 & & 95 & 4 & \\
\hline Apr $14, ' 88$ & 0.5 & 2 & 49 & 44 & 3 & \\
\hline Apr 26,88 & & 2 & 43 & 48 & 7 & 0.3 \\
\hline May 19, 88 & & & 22 & 72 & 5 & \\
\hline Jun $10, ' 88$ & & 0.2 & 10 & 88 & 1 & \\
\hline Jul $27, ' 87$ & & & 3 & 85 & 11 & \\
\hline Sep 03, '87 & & & & 100 & & \\
\hline Oct $26, ' 84$ & & & 10 & 90 & & \\
\hline
\end{tabular}

There were no major differences in the vertical day/ night profiles of total zooplankton biomass or concentrations of Calanus spp. below $80 \mathrm{~m}$. Above $80 \mathrm{~m}$ there was a slight increase in biomass at night due to the upward migration of euphausiids (Fig. 6). Calanus spp. below $80 \mathrm{~m}$ were mainly resting stage individuals that probably remained at these depths until the following spring.

\section{Vertical distribution of Calanus spp. stages}

Calanus finmarchicus concentrations between 50 and $200 \mathrm{~m}$ from June to October were usually $<50 \mathrm{~m}^{-3}$ during both day and night. The copepodites in this depth range were primarily $\mathrm{CIV}$ and $\mathrm{CV}$, with $\mathrm{CV}$ dominating. However, small numbers of $\mathrm{CIII}$ and $\mathrm{CII}$ were found below $200 \mathrm{~m}$ during April and June (Table 3). Copepodite Stages CI to CIII were concentrated in the upper $40 \mathrm{~m}$ during all sample periods. Below $200 \mathrm{~m}$ during February to June $C$. finmarchicus males and females were common indicating that some individuals were reproducing. After June the percentage of males and females dropped, primarily because of increased CVs of the new generation. 


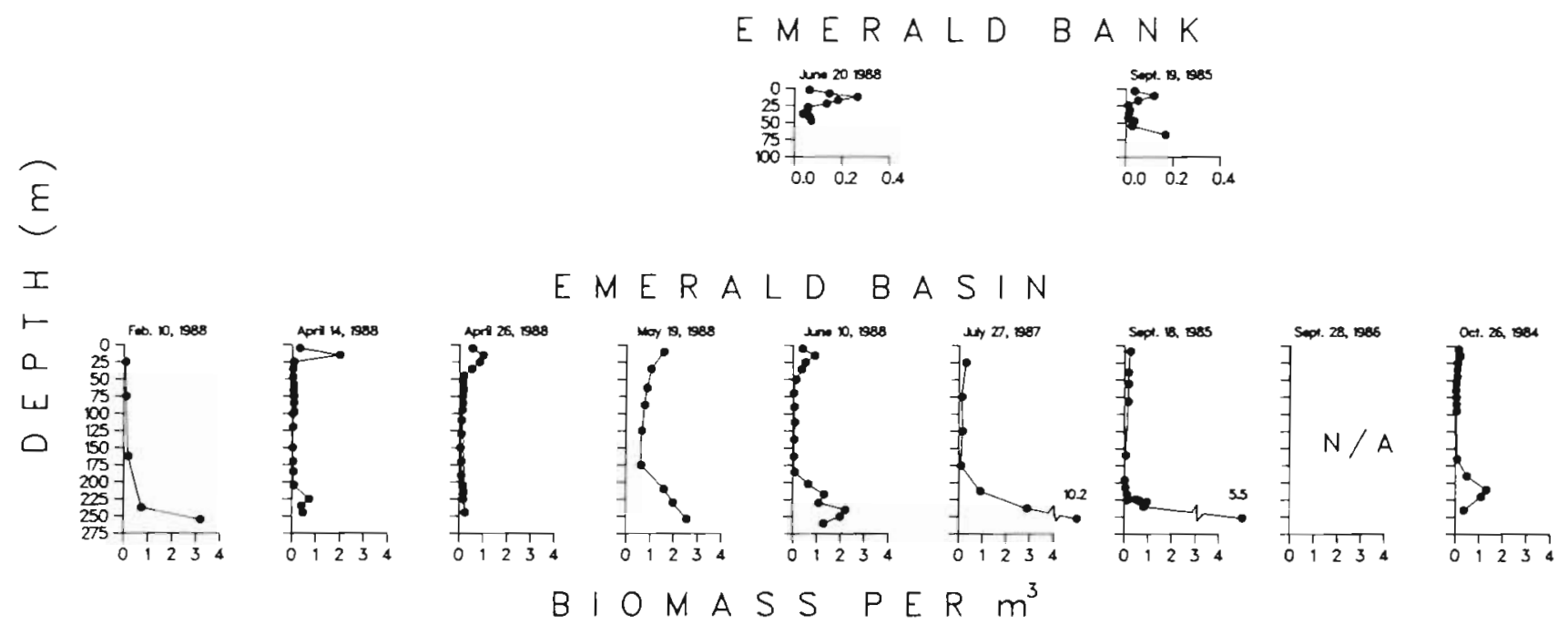

Fig. 7. Vertical distribution of total zooplankton biomass $\left(\mathrm{g} \mathrm{m}^{-3}\right)$ for Emerald Basin through the year and Emerald Bank for June and September

Calanus glacialis $\mathrm{CV}$ was the only stage of this species found below $200 \mathrm{~m}$ during February, whereas Stages CIV and CV were dominant between April and September. In October CV was the dominant stage of C. glacialis. No males were found and only a small number of females were seen in early April (Table 3 ), suggesting that $C$. glacialis did not breed in the Emerald Basin area.

Copepodite CIV was the most common stage of $C$. hyperboreus during all months but April. In April CIII. CIV, CV, and male and female CVI were present (Table 3).

\section{Seasonal distribution of copepod biomass}

Depth profiles of the total zooplankton biomass $\left(\mathrm{g} \mathrm{m}^{-3}\right)$ in Emerald Basin showed a biomass maximum between 230 and $250 \mathrm{~m}$ during May to October (Fig. 7) with the highest concentration $\mathrm{m}^{-3}$ found in July. The lowest total biomass $\left(\mathrm{g} \mathrm{m}^{-2}\right)$ occurred during February and the highest in May (Table 4). No samples were collected between November and February, so it is unknown if the biomass $\mathrm{m}^{-2}$ continued to increase or decreased after October.

The biomass $\mathrm{m}^{-3}$ in the upper $50 \mathrm{~m}$ of Emerald Basin

Table 4. Total zooplankton and euphausiid wet biomass $\mathrm{m}^{-2}\left(\mathrm{~g} \mathrm{~m}^{-2}\right)$

\begin{tabular}{|c|c|c|c|c|}
\hline Dàte & $\begin{array}{l}\text { Total zooplankton biomass } \\
\text { in entire water column }\end{array}$ & $\begin{array}{l}\text { Total zooplankton } \\
\text { in bottom } 100 \mathrm{~m}\end{array}$ & $\begin{array}{l}\text { Euphausiid biomass in } \\
\text { entire water column }\end{array}$ & $\begin{array}{c}\text { Percentage of total water column } \\
\text { biomass in bottom } 100 \mathrm{~m}\end{array}$ \\
\hline \multicolumn{5}{|c|}{ Emerald Basin } \\
\hline Feb $10, ' 88$ & 34.4 & 30.9 & 0.4 & 90 \\
\hline Apr 14,' 88 & 47.4 & 20.4 & 3.1 & 27 \\
\hline Apr 26,88 & 55.0 & 17.5 & 3.2 & 32 \\
\hline May 19,88 & 308 & 141 & 14.6 & 46 \\
\hline Jun 0?, 87 & 72.5 & 59.6 & 0.9 & 82 \\
\hline Jun 10, ' 88 & 92 & 63.2 & 8.0 & 69 \\
\hline Jul 27, '87 & 178 & 157 & 2.0 & 88 \\
\hline Sep 18, 85 & 94.5 & 76.9 & 1.0 & 81 \\
\hline Oct $26, ' 84$ & 66.3 & 58.1 & 6.2 & 88 \\
\hline \multicolumn{5}{|c|}{ La Have Basin } \\
\hline Apr 14,88 & 179 & 89 & 25.2 & 50 \\
\hline Jun $08, ' 88$ & 110 & 79 & 29.5 & 72 \\
\hline Jul 30,87 & 518 & 481 & 1.0 & 93 \\
\hline Oct $28, \cdot 84$ & 46.8 & 31.6 & 1.6 & 68 \\
\hline \multicolumn{5}{|c|}{ Louisbourg Basin } \\
\hline Sep 28, ' 85 & 228 & 212 & 1.3 & 93 \\
\hline
\end{tabular}


was about 5 times greater than it was at the same depths on Emerald Bank during June. During September the values were similar in the basin and on the bank (Fig. 7). Data from the optical zooplankton counter towed on a Batfish over transects across Emerald Basin and Bank at the same times as the BIONESS sampling confirmed the large differences seen in zooplankton concentrations with the BIONESS (Herman pers. comm.).

Copepods represented up to $90 \%$ of the total zooplankton biomass below $200 \mathrm{~m}$ in the basins with the euphausiids, primarily Meganyctiphanes norvegica, the second most important group, making up between 1 and $27 \%$ of the biomass. No other single group of animals made up more than $1 \%$ of the total biomass in the deep regions of the basins.

The body volumes of Calanus hyperboreus CIV and $\mathrm{CV}$ are 2.8 and 11.7 times the body volume of $C$. finmarchicus CV (Herman 1988). If it is assumed that the specific densities per unit volume of these 2 species are the same, then it is possible to estimate the percentages of the total Calanus biomass of each of the species represented in the deep regions of the basins. This was done by taking the total volume of the different stages of each species relative to the volume of $C$. finmarchicus $\mathrm{CV}$, and assuming these volume percentages were equal to weight-based percentages. Based on these assumptions $C$. hyperboreus represented a majority of the Calanus biomass in the deep regions of Emerald Basin from February to June and almost equalled the biomass contribution of $C$. finmarchicus for the other months (Table 2). In Louisbourg Basin in October C. hyperboreus dominated the biomass and the contribution of $C$. glacialis to the biomass equalled that of C. finmarchicus.

\section{DISCUSSION}

Emerald Basin acts as an accumulation site for Calanus finmarchicus, C. glacialis and C. hyperboreus that undergo seasonal migration when they reach Copepodite CIV and CV. Such basins probably collect the copepodites that developed in the water immediately over them and also migrating individuals carried into them by currents from shallower regions. This results in a higher concentration of Calanus in the deep basins than would be expected from the production in the water column of the basin. The general direction of currents on the Nova Scotia shelf in the is from NE to SW (Smith \& Petrie 1982, Herman et al. in press) which means that some of the copepods in the basins likely originated from the NE regions of the shelf, or from the Gulf of St. Lawrence. Head (unpubl.) found the species composition of Calanus in the Strait of Belle Isle region of the Gulf of St. Lawrence was similar to that of Louisbourg Basin, which may explain how C. glacialis and $C$. hyperboreus accumulated in Emerald Basin during the summer when there was no evidence of reproduction in the upper layers. Below $100 \mathrm{~m}$ (the sill depth) the basin is a very quiet physical environment with the mean current below $200 \mathrm{~m}$ in the spring to fall period only $0.008 \mathrm{~m} \mathrm{~s}^{-1}$ and the low frequency RMS amplitude $0.06 \mathrm{~m} \mathrm{~s}^{-1}$ (Herman et al. in press). These weak currents enable Calanus to accumulate below $200 \mathrm{~m}$ and remain there for the winter.

Large populations of Meganyctiphanes norvegica are found in all the basins whereas few were found on the shallow plains or the banks (Lewis \& Sameoto 1988a, b, c, 1989). M. norvegica needs high concentrations of copepods to survive and grow (Sameoto 1980, McClathie 1985); therefore the high concentrations of Calanus spp. in the deep basin provided a favourable growing environment for the euphausiids the year around. The high concentrations of copepods and euphausiids in Emerald and La Have Basins may also be attractive to juvenile and adult silver hake Merluccius bilinearis, in the basin (Cochrane et al. in press), copepods and euphausiids make up a large part of the diet of the silver hake (Koeller et al. 1989).

There was a large decrease in the numbers of the Calanus spp. populations in Emerald Basin over the winter. There are 3 likely explanations: (1) that the population of Calanus spp. was grazed by predators such as the euphausiids and silver hake; (2) possibly that a large part of the population in the deep water migrated vertically to the upper $50 \mathrm{~m}$ prior to February 10 , meaning that some individuals started their seasonal migration as early as January; (3) that these copepods cannot survive on their oil reserves at temperatures between 8.5 and $10^{\circ} \mathrm{C}$ for the period from June to February. Respiration rates of the Calanus spp. from the deep water of the basin in June were at levels that would exhaust the oil reserves before the next spring. It is unknown if the rates remained at these levels through the full winter (Head, Bedford Institute of Oceanography, pers. comm.). None of these species feed while in the resting CV stage (Conover 1962, Hiche 1983).

In Emerald Basin females and males were present during all sampling periods (Table 1, Fig. 8), having their highest percentage of the total population in February (Table 5). The highest percentage of gravid females in the population of females occurred at the end of April, whereas the highest percentage of gravid females in the total population in was early in April (Table 5). There was an small increase in the percentage of gravid females in late July and August, when females represented up to $5 \%$ of the total population (Table 5). The main reproductive period for Calanus 


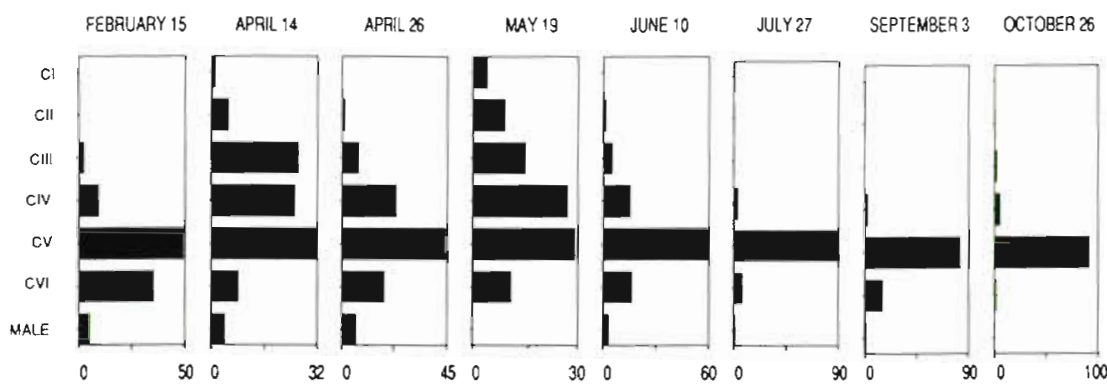

Fig. 8. Calanus finmarchicus. Seasonal distributions of copepodites in Emerald Basin as percentages of the total population

PERCENTAGE OF TOTAL POPULATION

finmarchicus was in April with a smaller one occurring in late July. However, when the total numbers of gravid females $\mathrm{m}^{-2}$ were compared at different times of the year they suggest that the July and September period may be equal to or more important than spring for reproduction (Table 1). In July and September the percentage of gravid females in the total population is much lower than in spring but the total number $\mathrm{m}^{-2}$ is higher due to the much higher total population (Table 1). In July and September the concentration of C. finmarchicus in the upper $50 \mathrm{~m}$ is much lower than in the spring. This may be the result of the copepods reaching Stage CV faster in 10 to $20^{\circ} \mathrm{C}$ water than in the 2 to $4^{\circ} \mathrm{C}$ water in the spring. The slower growth in the spring would cause the population of younger copepodites to accumulate in the upper $50 \mathrm{~m}$ resulting in a large population.

There were large numbers of CV and CVI copepods below $200 \mathrm{~m}$ in February that probably reproduced later in the year. Few Calanus finmarchicus were found below $200 \mathrm{~m}$ on April 14, suggesting that the overwintering population $\left(\mathrm{G}_{0}\right)$ had migrated to the surface waters to reproduce. Therefore, the main breeding period was probably between mid-February and midApril. The copepods that stated to accumulate below
$200 \mathrm{~m}$ in May were likely CIV and CV of the first new generation $\left(G_{1}\right)$ produced from eggs laid in mid-February. A large part of the total population remained in the surface waters from May to early July. These could have been $G_{1}$ copepods from late breeding $G_{0}$ individuals or they could have been $G_{2}$ or $G_{3}$ copepods that breed without going into a resting stage.

McLaren \& Corkett (1986) reported that Calanus finmarchicus collected from Emerald and Brown's Bank, south and southwest of Emerald and La Have Basins (Fig. 1), produced 2 generations per year, a large one in spring and a much smaller generation in late summer.

Estimates of the number of days it took Calanus finmarchicus to reach maturity at different temperatures were made using Corkett et al. (1986) Belehradek's temperature function

$$
D=a(T-10.6)^{-2.05}
$$

where $\mathrm{a}=17477 ; \mathrm{T}=$ water temperature $\mathrm{D}=$ days to reach maturity from hatching for $C$. finmarchicus.

Gravid females made up $2 \%$ of the total population during January and February (Table 5). If it is assumed that Calanus finmarchicus started to lay eggs on February $10-$ not an unreasonable assumption since $4 \%$ of

Table 5. Percentages of gravid females in total copepodite VI and total Calanus finmarchicus populations

\begin{tabular}{|c|c|c|c|}
\hline Date & $\begin{array}{l}\text { Percentage of female CVI in total } \\
\text { C. finmarchicus population }\end{array}$ & $\begin{array}{l}\text { Percentage of gravid females } \\
\text { in total CVI population }\end{array}$ & $\begin{array}{l}\text { Percentage of gravid } \\
\text { females in total population }\end{array}$ \\
\hline $\operatorname{Jan} 10,85^{a}$ & 21 & 8 & 2 \\
\hline Feb 10, '81 & 57 & 4 & 2 \\
\hline Feb 10, '88 & 47 & 11 & 5 \\
\hline Apr $14, ' 88$ & 29 & 40 & 32 \\
\hline Apr $26,{ }^{\prime} 88$ & 17 & 37 & 8 \\
\hline Jun 10,88 & 14 & 33 & 5 \\
\hline Jun $07, ' 87$ & 10 & 5 & 0.5 \\
\hline Jul 06, ' 87 & 11 & 6 & 0.6 \\
\hline Jul 27,87 & 14 & 35 & 5 \\
\hline Aug 27,76 & 35 & 10 & 3.5 \\
\hline Sep 28,86 & 10 & 10 & 1 \\
\hline Oct 26,84 & 13 & 3 & 0.4 \\
\hline
\end{tabular}


Table 6. Calanus finarchicus. Estimated number of generations using Belehradek's growth equation (Corkett \& McLaren's (1986). Generation $\mathrm{G}_{4}$ reaches Stage CV in $22.7 \mathrm{~d}$ or Day 256 when it is assumed to migrate into deep water and goes into a resting stage

\begin{tabular}{|cccccc|}
\hline Parent generation & $\begin{array}{c}\text { Day of the } \\
\text { year they reproduce }\end{array}$ & $\begin{array}{c}\text { Date they } \\
\text { reproduce }\end{array}$ & $\begin{array}{c}\text { Water } \\
\text { temperature }\left({ }^{\circ} \mathrm{C}\right)\end{array}$ & $\begin{array}{c}\text { No. of days from } \\
\text { egg to Stage CVI }\end{array}$ & New generation \\
\hline $\mathrm{G}_{0}$ & 46 & Feb 10 & 2 & 97 & $\mathrm{G}_{1}$ \\
$\mathrm{G}_{1}$ & 143 & May 18 & 6 & 35 & $\mathrm{G}_{2}$ \\
$\mathrm{G}_{2}$ & 198 & July 12 & 10 & $\mathrm{G}_{3}$ \\
$\mathrm{G}_{3}$ & 233 & Aug 18 & 12 & 29 & $\mathrm{G}_{4}$ \\
\hline
\end{tabular}

the female CVI were spent on this date (Table 1) - an estimated 4 generations could be produced by September if each generation omitted the resting stage (Table 6). These calculations of the number of generations are obviously much too simple, since they do not consider other environmental factors besides temperature, but the above data suggests that more than 2 generations are possible.

If there are only 2 generations as suggested by McLaren et al. (1989), then how do we explain the presence of gravid females during all months sampled from January to October? Possibly a small number of females laid eggs in January and February that developed into Stage CIV or CV copepodites that migrated into the deep water during May and remained in the resting stage until the next winter. A second possibility is that they may remain in the deep water for only a short time before maturing and returning to the surface to reproduce the late summer generation. The presence of large numbers of gravid and developing females below $200 \mathrm{~m}$ from June to September suggests that this may happen. If this is so then the life cycle of Calanus finmarchicus is not as simple as suggested by McLaren et al. (1989).

McLaren et al. (1989) estimated yearly production and turnover rate of Calanus finmarchicus on Emerald Bank, an area about $60 \mathrm{~km}$ south of Emerald Basin. They assumed 2 generations per year, with the second generation overwintering as CV. They also assumed that all females plus one-half the copepodites of each generation survived to reproduce 250 eggs each. The size of the cohort of the overwintering population in February was estimated to be $22.6 \mathrm{~m}^{-3}$ and this cohort $\left(G_{0}\right)$ produced the first new generation $\left(G_{1}\right)$. The size of the $G_{1}$ breeding cohort in early June was estimated to be between 8.0 and $7.8 \mathrm{~m}^{-3}$ which produced generation $\mathrm{G}_{2}$. The size of the reproducing cohort $\mathrm{G}_{2}$ in early August was $1.7 \mathrm{~m}^{-3}$. The assumptions McLaren et al. (1989) made were also made in estimating production of C. finmarchicus in Emerald Basin. To estimate cohorts it was assumed that only copepods in the upper $50 \mathrm{~m}$ were potential breeders. This overcame the problem of the large numbers of resting individuals that accumulated in the deep water of the basin. In the present study the estimated size of the cohort for $G_{0}$ was $121 \mathrm{~m}^{-3}$ in February, $133 \mathrm{~m}^{-3}$ for $G_{1}$ in early June and $196 \mathrm{~m}^{-3}$ for $\mathrm{G}_{2}$ in late July. These cohort values are 5.3 to 115 times larger than the cohorts on Emerald Bank found by McLaren et al. (1989), which suggests that $C$. finmarchicus production within basins was probably between 1 and 2 orders of magnitude greater than that on Emerald Bank, which was estimated at $122 \mathrm{mg}$ dry wt $\mathrm{m}^{-3}$ (McLaren et al. 1989). We could not calculate with any more confidence the production of C. finmarchicus in Emerald Basin for 3 reasons. First, we lacked an adequate time series of samples. Second, with the accumulation of $\mathrm{CV}$ and CIV copepodites in the deep water there was no way of telling if these individuals all originated from the basin region, or if they were advected from some other area. Third, the percentage of generation $G_{1}$ which migrated into deep water and the percentage that produced generation $G_{2}$ are unknown.

The high estimated yearly production of Calanus finmarchicus combined with the accumulation of very high concentrations of Calanus spp. below $200 \mathrm{~m}$ make Emerald and the other basins regions of exceptionally high biological activity. Different regions of the shelf probably have different $C$. finmarchicus production levels depending on the size of the initial breeding population and the size of the basins. Therefore it is not possible to extrapolate the results from a small region to the entire shelf or parts of the shelf.

The low concentrations of Calanus finmarchicus between 50 and $200 \mathrm{~m}$ during day and night between May and October may be due to a slow downward migration of Stages CIVand CV rather than a single mass migration. If so, than there may be a continuum of ages of CIV and CV in the layers below $200 \mathrm{~m}$ that may reproduce at different times in the late winter and spring. C. glacialis and C. hyperboreus accumulated in the basin possibly by being carried to the basin by advection from the coastal Scotia Current, which contains concentrations of C. hyperboreus CIV and CV that conceivably originated from the Gulf of St. Lawrence (Herman et al. in press) or from Labrador Current water that is advected on to the shelf.

The vertical distribution of Calanus spp. in Emerald 
Basin was similar from May to October. Concentrations increased below $200 \mathrm{~m}$ and continued to increase until about 240 to $250 \mathrm{~m}$, after which depth there was generally a decrease near the bottom. This decrease near the bottom may have been due to predation by high concentrations of Meganyctiphanes norvegica on the bottom. Photographic and video observations showed the bottom $2 \mathrm{~m}$ to have high concentrations of euphausids and chaetognaths (Cochrane et al. in press). During the day there is also a large population of juvenile silver hake and sandlance Ammodytes americanus on the bottom (J. Nielson, Department of Fisheries and Oceans, St. Andrews, N.B., pers. comm.). All of these species are potential predators of Calanus spp. near the bottom.

This study has shown that the basins on the Nova Scotia shelf are distinctly different from the shallow plains and banks. The accumulation of Calanus spp. in the deep water may provide the food base for larger macrozooplankton and fish. Basins greater than $200 \mathrm{~m}$ depth make up only about $5 \%$ of the shelf area, but in the fall the biomass of zooplankton in the basins was estimated to be up to $50 \%$ of the total zooplankton biomass on the shelf (Lewis \& Sameoto 1988a, b, c, 1989). The fall Calanus population below $200 \mathrm{~m}$ in the basins represented $56 \%$ of the total Calanus population on the shelf. This estimate was based on an autumn concentration of Calanus in the upper $200 \mathrm{~m}$ of the entire shelf of $10450 \mathrm{~m}^{-2}$ and a concentration of $301920 \mathrm{~m}^{-2}$ below $200 \mathrm{~m}$ in the basins (Sameoto unpubl.).

The deep basins on the Nova Scotia shelf influence the composition of the zooplankton community of the shelf. If the basins did not exist it is likely the Nova Scotia shelf zooplankton would resemble that of the the Grand Banks which is dominated by microzooplankton and gelatinous zooplankton, with Calanus spp. a minor component advected on to the edge of the bank from the slope water (Anderson \& Gardner 1986). Krause \& Trahms (1983) discussed the origins of C. finmarchicus on the North Sea shelf, which has no deep basins, and came to the conclusion that the population is replenished each spring by transport from the deep waters from the shelf edge, since the absence of deep basins on the North Sea shelf resulted in C. finmarchicus being advected off the shelf each year. Clearly, to understand the production of the Nova Scotia shelf we must have a better understanding of the production in the basin regions and the physical processes that cause copepods to accumulate and remain in them.

Acknowledgements. We would like to express our appreciation to Drs A. Longhurst and $R$. J. Conover for their thoughtful reviews of the manuscript, to $\mathrm{Ms} \mathrm{M}$. K. Lewis and $\mathrm{Mr} B$. Fraser for their able technical assistance during the cruises and in data analysis, and the officers and crew of the CSS 'Dawson' for their help during the many cruises.

\section{LITERATURE CITED}

Anderson, J. T., Gardner, G. A. (1986). Plankton communities and physical oceanography observed on the southeast shoal region, Grand Bank of Newfoundland. J. Plankton Res. 8: 1111-1135

Cochrane, N. A., Sameoto, D. D., Herman, A. W., Nielson, J. (in press). Multiple frequency acoustic backscattering and zooplankton aggregations in the inner Scotian shelf basins. Can. J. Fish. Aquat. Sci.

Conover, R. J. (1962). Metabolism and growth in Calanus hyperboreus in relation to its life cycle. Rapp. P.-v. Réun. Cons. perm. int. Explor. Mer 153: 190-197

Conover, R. J. (1988). Comparative life histories in the genera Calanus and Neocalanus in high latitudes of the northern hemisphere. Hydrobiologia 167: 127-142

Corkett, C. J., McLaren, I. A., Sevigny, J.-M. (1986). The rearing of the marine calanoid Calanus finmarchicus (Gunnerus), C. glacialis Jaschnov and C. hyperboreus Kroyer with comment on the equiproportional rule (Copepoda). Proc. Second Internat. Conf. on Copepoda in Syllogeus. Natn. Mus. Canada 58: 539-546

Drinkwater, K., Taylor, G. (1982). Monthly means of the temperature, salinity and density along the Halifax section. Can. Tech. Rep. Fish. Aquat. Sci. 1093: 1-67

Drinkwater, K. F., Trites, R. W. (1987). Monthly temperature and salinity in the Scotian shelf region. Can. Tech. Rep. Fish. Aquat. Sci. 1539: 1-101

Herman, A. W (1988). Simultaneous measurement of zooplankton and light attenuance with a new optical plankton counter. Cont. Shelf Res. 8: 205-221

Herman, A. W., Sameoto, D. D., Chen Shunnian, Mitchell, M. R., Petrie, B., Cochrane, N. (in press). Sources of zooplankton on the Nova Scotia shelf and their aggregations within deep shelf basins. Cont. Shelf Res.

Hirche, H. J. (1983). Overwintering Calanus finmarchicus and Calanus helgolandicus. Mar. Ecol. Prog. Ser. 11: 281-290

Koeller, P., Coates-Markle, L., Nielson, J. D. (1989). Feeding ecology of juvenile ( 0 -group silver hake) Merluccius bilinearis on the Scotian Shelf. Can. J. Fish. Aquat. Sci. 46: 1762-1768

Krause, M., Trahms, J. (1983). Zooplankton dynamics during FLEX '76. In: Sundermann, J., Lenz, W. (eds.) North Sea dynamics. Springer-Verlag, New York, p. 632-661

Lewis, M. K., Sameoto, D. D. (1988a). The vertical distribution of zooplankton on the Nova Scotia slope - April 1983. Can. Data Rep. Can. J. Fish. Aquat. Sci. 682: 1-46

Lewis, M. K., Sameoto, D. D. (1988b). The vertical distribution of zooplankton and ichthyoplankton on the Nova Scotia shelf - October 1981. Can. Data Rep. Can. J. Fish. Aquat. Sci. $684: 1-106$

Lewris, M. K., Sameoto, D. D. (1988c). The vertical distribution of zooplankton and ichthyoplankton on the Nova Scotia shelf - April 1984. Can. Data Rep. Can. J. Fish. Aquat. Sci. 717: $1-64$

Lewis, M. K., Sameoto, D. D. (1989). The vertical distribution of zooplankton and ichthyoplankton on the Nova Scotia shelf - October 1984. Can. Data Rep. Fish. Aquat. Sci. 731: 1-80

McClatchie, S. (1985). Feeding behavior in Meganyctiphanes norvegica (M. Sars) (Crustacea: Euphausiacea). J. exp. mar Biol. Ecol. 86: 271-284

McLaren, I. A.., Corkett, C. J. (1986). Life cycles and production of two copepods on the Scotian shelf, eastern Canada. Proc. Second Internat. Conf. on Copepoda in Syllogeus Natn. Mus. Can. 58: 362-368

McLaren, I. A., Tremblay, M. J., Corkett, C. J., Roff, J. C. 
(1989). Copepodproduction on the Scotianshelf based on lifehistory analyses and laboratory rearings. Can. J. Fish. Aquat. Sci. 46: 560-583

Motoda, S. (1959). Devices of simple plankton apparatus Mem. Fac. Fish. Hokkaido Univ. 7: 73-94

O'Boyle, R. N., Sinclair, M., Conover, R. J., Mann, K. H. Kohler, A. C. (1984). Temporal and spatial distribution of ichthyoplankton communities of the Scotian Shelf in relation to biological, hydrological and physiographic features. Rapp. P.-v. Réun. Cons. perm. int. Explor. Mer 183: 27-40

Ostvedt, O.-J. (1955). Zooplankton investigations from weather ship $M$ in the Norwegian Sea, 1948-49. Havsforsk Inst. Skr., Helsingf. 40: 1-93

Rowell, T W., Young, J. H., Poulard, J. C., Robin, J. P. (1985). Changes in distribution and biological characteristics of Illex illecebrocsus on the Scotian shelf, 1980-83. NAFO Sci. Coun. Studies 9: 11-26

Sameoto, D. D. (1980). Relationships between stomach contents and vertical migration in Meganyctiphanes norvegica, Thysanoessa rashii and $T$. inermis (Crustacea, Euphausiacea). J. Plankton Res. 2: 129-143

This article was submitted to the editor
Sameoto, D. D. (1982). Zooplankton and micronekton abundance in acoustic scattering layers on the Nova Scotian slope. Can. J. Fish. Aquat. Sci. 39: 760-777

Sameoto, D. D. (1984). Environmental factors influencing diurnal distribution of zooplankton and ichthyoplankton. J. Plankton Res. 6: 767-792

Sameoto, D. D., Cochrane, N. A., Herman, A. W. (1985). Response of biological acoustic backscattering to ship's lights. Can. J. Fish. Aquat. Sci. 42: 1535-1543

Sameoto, D. D., Herman, A., Longhurst, A. (1986). Relations between the thermocline meso- and microzooplankton, chlorophyll $a$ and primary production distribution in Lancaster Sound. Polar Biol. 6: 53-61

Sameoto, D. D., Jaroszynski, L. O., Fraser, W. B. (1980). BIONESS, a new design in multiple net zooplankton samplers. Can. J. Fish. Aquat. Sci. 37: 722-724

Smith, P. C., Petrie, B. D. (1982). Low-frequency circulation at the edge of the Scotian shelf. J. phys. Oceanogr. 12: 28-46 Tremblay, M. J., Roff, J. C. (1983). Community gradients in the Scotian Shelf zooplankton. Can. J. Fish. Aquat. Sci. 40: 598-611

Manuscript first received: January 16, 1990

Revised version accepted: May 29, 1990 